\title{
PELAKSANAAN PENGASUHAN DI TAMAN ANAK SEJAHTERA
}

\author{
Nurfadilah, Rohita \& Nila Fitria \\ e-mail: novanurfadilah@uai.ac.id; rohita@uai.ac.id; nilafitria@uai.ac.id \\ Fakultas Psikologi dan Pendidikan, Universitas Al-Azhar Indonesia, Jakarta
}

\begin{abstract}
Abstrak: Taman Anak Sejahtera (TAS) adalah salah satu bentuk pelayanan sosial yang bertujuan untuk memberikan perawatan, pengasuhan dan perlindungan kepada anak usia tiga bulan sampai dengan delapan tahun. Penelitian ini bertujuan untuk mendeskripsikan bagaimana prinsip penyelenggaraan TAS dilaksanakan. Penelitian dilaksanakan Agustus-Oktober 2016 di Taman Anak Sejahtera (TAS) di tiga wilayah Jakarta. Metode penelitian yang digunakan adalah metode deskriptif-kualititatif, dengan teknik pengambilan data berupa observasi, wawancara, dan dokumentasi. Sementara analisis data dilakukan dengan menggunakan teknik analisis data kualitatif. Penelitian ini dilakukan di tiga TAS kota Jakarta, yaitu TAS Lentera Nusantara di Jakarta Selatan, TAS Akur Kurnia di Jakarta Timur, dan TAS Kesuma di Jakarta Pusat. Pemilihan ketiga TAS tersebut didasarkan atas pertimbangan yang diberikan oleh Kementerian Sosial RI sebagai Departemen yang menaungi keberadaan TAS. Hasil penelitian diketahui bahwa pengasuh belum dapat memberikan layanan pengasuhan yang meliputi layanan kesehatan dan gizi, pendidikan, serta pengasuhan dan perlindungan sesuai dengan tujuan penyelenggaraan TAS.
\end{abstract}

Kata-kata kunci: TAS, pengasuh, layanan kesehatan dan gizi, layanan pendidikan, layanan pengasuhan dan perlindungan

\section{NURTURING IN TAMAN ANAK SEJAHTERA}

\begin{abstract}
Taman Anak Sejahtera (TAS) is one of the forms of social service which aims to provide treatment, care and protection to children of three months up to eight years. The purpose of this study is to describe the implementation of nurturing principles in TAS. The study was conducted in Jakarta as from August through October 2016 applying descriptive-qualitative method, with data collection techniques such as observation, interviews, and documentation. While, the data was analyzed using qualitative data analysis techniques. This research was conducted at TAS Lentera Nusantara in South Jakarta, TAS Akur Kurnia in East Jakarta, and TAS Kesuma in Central Jakarta. The selection of the three TAS is based on the consideration given by the Ministry of Social Affairs as the Department which supervises the existence of TAS. The results from this study revealed that caregivers can not provide care services that include health and nutrition, education, and care and protection in accordance with the objectives of TAS.
\end{abstract}

Keywords: TAS, caregivers, health care and nutrition, education, care and protection services

\section{PENDAHULUAN}

Anak membutuhkan orang dewasa atau lingkungan agar dapat mencapai tumbuh kembang yang optimal. Keluarga sebagai pendidik yang pertama dan utama dalam mengembangkan berbagai potensi yang dimiliki oleh anak dapat memberikan pengasuhan yang sesuai dengan usia dan tahap perkembangan anak. Namun, terdapat orangtua yang tidak mampu melakukan pengasuhan secara penuh kepada anak karena keduanya harus bekerja. Terdapat beberapa solusi yang dapat ditempuh orangtua, seperti dengan mencari tenaga pengasuh sebagai perpanjangan tangan orang tua selama orang tua bekerja di luar rumah atau dengan menitipkan anak di lembaga penitipan anak.

Terdapat beberapa istilah yang digunakan untuk lembaga penitipan anak, namun jika dilihat dari jalur perijinan, terdapat dua istilah, yaitu Taman Penitipan Anak (TPA) yang dikelola oleh Kementerian Pendidikan dan Kebudayaan dan Taman Anak Sejahtera (TAS) yang dikelola oleh Kementerian Sosial (Kemensos). Menurut Peraturan Menteri Sosial R.I No. 02 Tahun 2012 tentang Taman Anak Sejahtera (TAS), yang dimaksud dengan TAS adalah salah satu bentuk pelayanan sosial yang bertujuan 
untuk memberikan perawatan, pengasuhan, dan perlindungan kepada anak usia tiga bulan sampai dengan usia delapan tahun.

Disebutkan pula, salah satu prinsip penyelenggaraan TAS adalah holistik dan integratif yang terlihat dari bentuk kegiatan (a) mendidik anak melalui pembelajaran sosial, adaptasi, kognitif dan psikomotorik; (b) merawat anak melalui pemeriksaan kesehatan, pengobatan, konsultasi dan pemeliharaan kesehatan; serta (c) membimbing orang tua atau keluarga melalui layanan konsultasi psikologi dan sosial. Selain itu, disebutkan pula, fungsi orangtua/wali dibantu oleh TAS dalam upaya pemenuhan kesejahteraan anak sehingga anak memperoleh pengasuhan secara utuh untuk dapat tumbuh, berkembang, berpartisipasi dan bersosialisasi baik secara individu maupun kelompok sehingga dapat menjadi anak yang sehat, cerdas, ceria, dan berakhlak mulia.

Upaya Kemensos dalam pengembangan anak usia dini yang diatur dalam Permensos No.2 Tahun 2012 tentang TAS tersebut sudah sejalan Peraturan Presiden (Perpres) No.60 Tahun 2013 tentang Pengembangan Anak Usia Dini Holistik Integratif (PAUD HI). Studi terkait PAUD HI belum banyak dilakukan namun terdapat satu studi yang cukup komprehensif, yaitu studi yang dilakukan oleh Kementerian Perencanaan Pembangunan Nasional (KPPN)/Badan Perencanaan Pembangunan Nasional (Bapenas) tahun 2013, yang berjudul Studi Strategi Pengembangan Anak Usia Dini.

Studi tersebut membahas lembaga PAUD secara umum sehingga tidak ditemukan yang khusus dikaitkan dengan TAS. Oleh karena itu, penelitian ini difokuskan pada TAS yang hasilnya dapat digunakan oleh Kemensos RI untuk ditindaklanjuti secara lebih mendalam. Penelitian ini menggunakan Pedoman Umum Pengembangan Anak Usia Dini Holistik Integratif (Bapenas, 2009) sebagai acuan penelitian mengingat petunjuk teknis terkait hal tersebut belum ada.

Dengan demikian, tujuan penelitian ini adalah untuk mengetahui pengasuh TAS memberikan layanan pengasuhan, perawatan, dan perlindungan kepada anak-anak asuhnya.

\section{Pengasuhan}

Pengasuhan dalam Kamus Besar Bahasa Indonesia diartikan sebagai cara mengasuh sedangkan menurut Hastuti (2010) pengasuhan diartikan sebagai pengalaman, keterampilan, dan tanggung jawab sebagai orang tua dalam mendidik dan merawat anak. Merujuk kepada Peraturan Menteri Sosial Republik Indonesia No.02 Tahun 2012 tentang Taman Anak Sejahtera (TAS), pengasuhan anak didefinisikan sebagai kegiatan pemenuhan kebutuhan esensial anak balita untuk dipelihara, dirawat, dibimbing, dididik dan dibina secara berkesinambungan agar anak dapat tumbuh kembang secara optimal, baik fisik, mental, spiritual dan sosial. Dengan demikian, dapat dikatakan bahwa pengasuhan merupakan bentuk interaksi dan pemberian stimulasi dari orang dewasa yang berada di sekitar kehidupan anak.

Prinsip pengasuhan menurut Hoghughi \& Long (2004: 1) tidak menekankan pada siapa (pelaku) namun lebih menekankan pada aktivitas perkembangan dan pendidikan anak. Oleh karenanya, pengasuhan meliputi fisik, emosi, dan sosial. Pengasuhan emosi mencakup pendampingan ketika anak mengalami kejadian yang tidak menyenangkan seperti merasa terasing dari temannya, takut, atau mengalami trauma.

Pengasuhan emosi ini mencakup pengasuhan agar anak merasa dihargai sebagai seorang individu, mengetahui rasa dicintai, serta memperoleh kesempatan untuk menentukan pilihan dan untuk mengetahui resikonya. Pengasuhan emosi ini bertujuan agar anak mempunyai kemampuan yang stabil dan konsisten dalam berinteraksi dengan lingkungannya, menciptakan rasa aman, serta menciptakan rasa optimistik atas hal baru yang akan ditemui oleh anak. Sementara itu, pengasuhan sosial bertujuan agar anak tidak merasa terasing dari lingkungan sosialnya yang akan berpengaruh terhadap perkembangan anak pada masa selanjutnya. Pengasuhan sosial ini menjadi sangat penting karena hubungan sosial yang dibangun dalam pengasuhan akan membentuk sudut pandang terhadap dirinya sendiri dan lingkungannya. pengasuhan sosial yang baik berfokus pada memberikan bantuan kepada anak untuk dapat terintegrasi dengan baik di lingkungan rumah maupun sekolahnya dan membantu mengajarkan anak akan tanggung jawab sosial yang harus diembannya (Hoghughi \& Long, 2004: 1).

Pengasuh merupakan tenaga pendidik di lembaga PAUD yang tugasnya diatur di dalam Peraturan Menteri Pendidikan dan Kebudayaan No.137 Tahun 2014 tentang Standar Nasional PAUD, yaitu merencanakan, melaksanakan pembelajaran, 
serta melakukan pembimbingan, pelatihan, pengasuhan dan perlindungan. Lebih lanjut, Surya (2007: 2) menjelaskan bahwa syarat untuk menjadi pengasuh adalah memiliki pengetahuan tentang kesehatan, kemampuan berbahasa yang jelas dan santun, memiliki kecerdasan yang cukup tinggi, serta berperilaku sopan dan santun.

\section{Taman Anak Sejahtera}

Taman Anak Sejahtera (TAS) adalah suatu pelayanan sosial yang diberikan pada anak usia tiga bulan sampai delapan tahun untuk mendapatkan pengasuhan, perawatan dan perlindungan bersifat sementara pada saat orang tua bekerja/berhalangan. Tujuan TAS adalah (1) terjaminnya tumbuh kembang anak berupa pengasuhan, perawatan dan perlindungan; (2) tersedianya kesempatan bagi anak untuk memperoleh pengasuhan, perawatan, perlindungan yang baik sehingga dapat terjamin kelangsungan hidup, tumbuh kembang dan partisipasi bagi anak; (3) terhindarnya anak dari kemungkinan memperoleh tindakan kekerasan atau tindakan lain yang akan mengganggu atau mempengaruhi kelangsungan hidup dan tumbuh kembang serta pembentukan kepribadian anak; serta (4) terbantunya orangtua/keluarga dalam memantapkan fungsi keluarga, khususnya dalam melaksanakan pembinaan kesejahteraan anak di dalam dan luar keluarga.

Pengasuhan dan perlindungan anak yang diberikan di dalam TAS mencakup kegiatan pemenuhan kebutuhan esensial anak melalui proses pemeliharaan, perawatan, bimbingan, pendidikan, dan pembinaan secara berkesinambungan agar anak dapat tumbuh kembang secara optimal, baik fisik, mental, spiritual maupun sosial, serta dapat berpartisipasi secara aktif sesuai dengan harkat, dan martabat kemanusiaan. Fungsi lembaga ini selain sebagai wahana penitipan anak balita, juga diperuntukkan bagi anak sampai dengan usia di bawah delapan tahun. Fungsi ini memberi peluang kepada orang tua yang berhalangan untuk waktu tertentu, serta dapat memanfaatkan TAS tanpa rasa takut atas resiko dari tindak kekerasan dan perlakuan salah lainnya.

Penyelenggaraan TAS mengacu pada sistem layanan holistik dan integratif, berbasis hak anak dan responsif terhadap kebutuhan terbaik bagi anak, berkesinambungan, berbasis budaya masyarakat yang konstruktif, etika layanan pada anak, dan pengasuhan antara. Di dalam penyelenggaraannya,
TAS memperhatikan prinsip dasar yaitu (1) holistik dan integratif , (2) berbasis hak anak dan kepentingan terbaik bagi anak, (3) berkesinambungan, dan (4) berbasis budaya yang konstruktif.

Program pelayanan bagi anak yang diberikan di TAS meliputi program pengasuhan yang terdiri (1) kegiatan pendidikan, merupakan kegiatan pembelajaran sosial meliputi pengembangan kognitif, psikomotorik dan afektif anak, yang dilakukan melalui pemberian stimulasi dan penyediaan lingkungan pembelajaran yang sesuai dengan tahapan usia; (2) perawatan, meliputi kegiatan pemeriksaan kesehatan, pengobatan, konsultasi dan pemeliharaan kesehatan, konsultasi kesehatan, dan pemeliharaan kesehatan; (3) perlindungan anak, mencakup segala kegiatan untuk menjamin dan melindungi anak dan haknya agar dapat hidup, tumbuh-kembang, terhindar dari diskriminasi serta berpartisipasi aktif dalam menentukan masa depannya. Tujuan yang ingin dicapai adalah terlindunginya anak dari berbagai bentuk penelantaran, eksploitasi, perlakuan salah, kekerasan dan diskriminasi; (4) pelayanan bagi orangtua, mencakup bimbingan dan penyuluhan bagi orangtua atau keluarga melalui layanan konsultasi psikologi dan sosial; dan pembinaan orangtua atau keluarga dan masyarakat melalui layanan rujukan dan informasi tentang pelayanan anak.

Penyelenggaraan TAS mengacu pada sistem layanan holistik dan integratif, berbasis hak anak dan responsif terhadap kebutuhan terbaik bagi anak, berkesinambungan, berbasis budaya masyarakat yang konstruktif, etika layanan pada anak, dan pengasuhan antara. Di dalam penyelenggaraannya, TAS memperhatikan prinsip dasar yaitu (1) holistik dan integratif, (2) berbasis hak anak dan kepentingan terbaik bagi anak, (3) berkesinambungan, dan (4) berbasis budaya yang konstruktif.

Selain memperhatikan prinsip dasar, TAS juga harus memperhatikan prinsip-prinsip khusus yaitu (1) jalankan dan ajarkan aturan agama, (2) kasih sayang, (3) disiplin dalam segala hal, (4) meluangkan waktu untuk bersama anak, (5) membedakan yang baik dan yang buruk, (6) saling menghargai (7) dengarkan anak, (8) latih dan kenali potensi anak, (9) kembangkan kemandirian, serta (10) pahami keterbatasan anak.

Hal lain yang perlu diperhatikan dalam menyelenggarakan TAS adalah sarana dan prasarana. Pengadaan dan pengembangan fasilitas TAS harus berorientasi pada pengembangan fungsi 
tumbuh kembang anak dan kondisi setempat. Lingkungan TAS harus dapat menciptakan suasana rasa aman kepada anak untuk belajar dan berkembang, sehingga anak merasa di rumahnya sendiri. Hal ini ditujukan untuk mengurangi rasa takut pada lembaga di mana anak dititipkan. Lingkungan di dalam hendaknya disusun dan direncanakan sesuai dengan kegiatan dan jumlah anak. Fasilitas yang terdapat di luar rungan harus dapat digunakan untuk kegiatan dan perkembangan motorik kasar anak-anak yang dititipkan.

\section{Pengembangan Anak Usia Dini Holistik Integratif (PAUD HI)}

Program intervensi bagi anak usia dini secara holistik dan integratif yang dilakukan sejak dalam kandungan merupakan salah satu bentuk pemenuhan hak anak, sesuai dengan Konvensi Hak Anak (KHA) yang disahkan oleh Badan PBB pada tahun 1989, serta UURI no 23 tahun 2002 tentang perlindungan anak. Kualitas perkembangan anak usia dini ditentukan oleh banyak faktor termasuk pemenuhan hak-hak anak untuk tumbuh dan berkembang secara optimal yang diselenggarakan secara integratif. Bappenas telah melakukan studi kebijakan terkait PAUD HI pada tahun 2006, menyusun strategi nasional PAUD $\mathrm{HI}$ pada tahun 2008, dan menyusun pedoman umum PAUD HI pada tahun 2009.

Program PAUD HI melibatkan berbagai sektor untuk memastikan kebutuhan esensial anak usia dini terpenuhi, diantaranya adalah sektor pendidikan, kesehatan, gizi dan perawatan, perlindungan dan pengasuhan anak. Oleh karena itu, pada tahun
2013 dikeluarkan Peraturan Presiden no. 60 tentang PAUD HI, sebagai acuan koordinasi lintas sektor pemerintah atau kementerian lembaga yang memiliki program terkait PAUD HI.

Tujuan umum dari PAUD $\mathrm{HI}$ adalah terselenggaranya layanan PAUD HI menuju terwujudnya anak Indonesia yang sehat, cerdas, ceria dan berakhlak mulia. Secara khusus, tujuan PAUD HI adalah (a) terpenuhinya kebutuhan esensial anak usia dini secara utuh meliputi kesehatan dan gizi, rangsangan pendidikan, pembinaan moralemosional dan pengasuhan sehingga anak dapat tumbuh dan berkembang secara optimal sesuai usia; (b) terlindunginya anak dari bentuk kekerasan, penelantaran, perlakuan salah dan eksploitasi di mana pun anak berada; (c) terselenggaranya pelayanan anak usia dini secara terintegrasi dan selaras antarlembaga layanan terkait sesuai kondisi wilayah; dan (d) terwujudnya komitmen seluruh unsur terkait yaitu orang tua, keluarga, masyarakat, pemerintah pusat dan pemerintah daerah dalam upaya PAUD HI.

Adapun sasaran program pelayanan PAUD $\mathrm{HI}$ terdiri dari (1) sasaran langsung, yaitu anak usia dini sejak janin dalam kandungan sampai dengan usia enam tahun; dan (2) sasaran tidak langsung, yaitu orang tua, keluarga, kader, tenaga kesehatan dan gizi, pendidik, pengasuh, masyarakat, organisasi sosial masyarakat, para pengambil kebijakan, berbagai penyelenggara layanan, dan pemangku kepentingan lainnya yang relevan dengan terpenuhinya kebutuhan esensial anak usia dini.

\section{METODE PENELITIAN}

Penelitian ini menggunakan metode penelitian deskriptif kualitatif, dimana peneliti ingin mendapatkan gambaran pengasuhan di TAS dalam bentuk layanan yang diberikan pengasuh TAS kepada anak-anak asuhnya. Pengasuhan ini fokus pada prinsip dasar penyelenggaraan TAS yang pertama, yaitu holistik integratif namun dijabarkan dalam lima bentuk layanan PAUD $\mathrm{HI}$ dengan menggunakan Pedoman Umum PAUD HI (BAPPENAS, 2009) dan Permensos No. 2 tahun 2012 sebagai acuan pembuatan panduan wawancara dan observasi. Hal ini dilakukan karena Kementerian Sosial belum memiliki pedoman atau juknis turunan dari Permensos No. 2 tahun 2012 tentang TAS. Adapun lima bentuk layanan PAUD HI adalah pendidikan, kesehatan, gizi dan perawatan, pendidikan, serta perlindungan dan kesejahteraan.

Pengambilan data dilakukan dengan menggunakan teknik purposive sampling, karena TPA yang akan dijadikan tempat penelitian telah ditentukan oleh pihak Kemensos RI. Setelah mendapat daftar TAS yang ditentukan oleh Kemensos RI, peneliti melakukan observasi proses kegiatan selama satu hingga dua jam di hari pertama kedatangan. Kemudian pada hari kedua, peneliti melakukan wawancara dengan salah satu pengasuh dan pengelola secara bergantian yang memakan waktu sekitar 1,5 jam. 
Penelitian dilaksanakan mulai bulan AgustusOktober 2016 di Taman Anak Sejahtera (TAS) di 3 wilayah Jakarta yaitu TAS LN di Jakarta Selatan, TAS K di Jakarta Pusat dan TAS AK di Jakarta Timur. Responden penelitian adalah perwakilan pengelola dan pengasuh dari tiap-tiap lembaga, dengan jumlah keseluruhan 6 orang. Jawaban yang diberikan pada saat wawancara langsung diperiksa kesesuaiannya dengan hasil pengamatan.

Pertanyaan yang terdapat di dalam daftar wawancara umumnya berupa fakta dan pengetahuan terkait lima layanan PAUD HI. Adapun teknik pemeriksaan keabsahan data yang diperoleh oleh peneliti adalah triangulasi. Adapun narasumber lain yang turut memverifikasi data yang diperoleh adalah pihak Kemensos RI yang memiliki tugas pokok dan fungsi terkait penyelenggaraan TAS.

Data yang terkumpul, dianalisis dengan menggunakan analisis data kualitatif. Analisis data kualitatif adalah upaya yang dilakukan dengan jalan bekerja dengan data, mengorganisasikan data, memilah-milahnya menjadi satuan yang dapat dikelola, menyintesiskannya, mencari dan menemukan pola, menemukan apa yang penting dan apa yang dipelajari, dan memutuskan apa yang dapat diceritakan kepada orang lain (Bogdan dan Biklen dalam Moleong, 2012).

\section{HASIL DAN PEMBAHASAN}

Pelaksanaan lima bentuk layanan PAUD HI yang terdiri dari pendidikan, kesehatan, gizi dan perawatan, pengasuhan, serta perlindungan dan kesejahteraan di setiap TAS adalah

\section{TAS LN}

TAS LN Jakarta Selatan didirikan dengan tujuan untuk membantu keluarga yang kurang mampu dan orang tuanya memiliki pekerjaan yang tidak tetap. TAS LN belum memiliki acuan dalam menyelenggarakan TAS tetapi telah memiliki izin pendirian yang diperoleh dari Kemensos RI. TAS LN berupaya mengoptimalkan pertumbuhan dan perkembangan anak dengan tidak mengambil alih tanggung jawab orang tua namun bekerjasama sebagai perpanjangan tangan orangtua ketika bekerja.

Layanan kesehatan dan gizi diberikan pengasuh dengan menyediakan perlengkapan $\mathrm{P} 3 \mathrm{~K}$; mendorong ibu untuk mendapatkan ASI eksklusif; serta membantu anak agar mendapatkan imunisasi lengkap, vitamin $A$, dan obat cacing. Pemberian vitamin A diberikan enam bulan sekali, bekerjasama dengan Puskesmas setempat. Selain itu, pengasuh menyajikan makanan tambahan berupa biskuit dan menyiapkan makanan sehat bergizi seimbang bagi anak tetapi belum ada dokumen menu yang tercatat meskipun dalam penerapannya melibatkan tenaga ahli seperti dokter dan bidan dari Puskesmas. Pengasuh memiliki pengetahuan dan keterampilan dasar untuk menerapkan program gizi dan kesehatan yang diperoleh dari diskusi dengan dokter, bidan, dan perawat di Puskesmas sehingga pengasuh dapat melakukan deteksi tumbuh kembang anak dan menyampaikan hasilnya kepada orangtua melalui kegiatan Temu Penguatan Anak dan Keluarga (TEPAK) atau merujuk anak ke Puskesmas dengan persetujuan orangtua jika permasalahan anak butuh penanganan tenaga ahli. TAS LN juga telah menerapkan pembiasaan hidup bersih dan sehat, seperti mencuci tangan sebelum makan, membuang sampah pada tempatnya dan toilet training.

Pelaksanaan layanan pendidikan dilakukan bersama mitra, yaitu lembaga PAUD dan salah satu pengasuh TAS LN juga seorang guru di PAUD tersebut. Kegiatan anak di TAS sudah memenuhi prinsip PAUD meskipun dalam penerapannya belum memiliki acuan dalam merencanakan, mengembangkan, dan mengevaluasi stimulasi perkembangan yang diberikan kepada anak. Selain itu, pengasuh belum pernah mendapatkan pengetahuan tentang layanan pengembangan anak usia dini dan tidak memiliki acuan pelaksanaan tindak lanjut dari hasil pemantauan tumbuh kembang anak. Pengasuh merasa belum membantu tumbuh kembang anak secara optimal dikarenakan media yang terbatas dan belum mengembangkan media dari bahan alam atau bahan daur ulang yang berbasis kearifan lokal.

Hasil observasi menunjukkan, lingkungan yang berada di dalam gang dengan luas sekolah $100 \mathrm{~m}^{2}$ membuat alokasi untuk sarana prasarana dan ruang gerak anak menjadi terbatas. Meskipun demikian, pemberian stimulasi pendidikan telah diberikan pengasuh sesuai dengan prinsip bermain sehingga tampak anak diberikan kebebasan untuk mengenali dan mengembangkan kompetensinya 
dengan menerapkan prinsip bermain sambil belajar. Anak-anak pun terlihat dapat merawat dirinya dan membantu orang lain seperti merapikan mainan setelah digunakan, cuci tangan sebelum makan, dan toilet training. Pengasuh melatih kreativitas anak melalui kegiatan bercerita dan mengajak anak berkomunikasi untuk mengembangkan kemampuan berbahasa. Anak di TAS didorong untuk berani mengajukan pertanyaan tanpa rasa takut, mengemukakan ide, mengembangkan, dan mewujudkan hasil pemikirannya. Pengetahuan dan keterampilan yang dimiliki oleh pengasuh diperoleh dari pelatihan yang diadakan oleh bagian pendidikan dan latihan Kemensos RI.

Layanan pengasuhan dan perlindungan yang pertama kali dilakukan oleh pengasuh di TAS LN yaitu mengajarkan anak untuk mengetahui nama, alamat, dan nama orang tua. Pengasuh mengajarkan kepada anak bagaimana melindungi dirinya, dengan cara mengajarkan bagian tubuh yang boleh disentuh dan tidak. Selain itu, pengasuh melibatkan orang tua dalam program yang dilakukan TAS seperti kegiatan TEPAK dengan mengundang narasumber dari pekerja sosial, Puskesmas, pemuka agama, serta kepolisian.

Berdasarkan hasil pengamatan mainan yang terdapat di TAS LN belum berlabel SNI (Standar Nasional Indonesia) namun secara berkala dilakukan pemeliharaan dan perawatan sarana dan prasarana. Selain itu, tampak pula bahwa pengasuh terbiasa untuk lebih banyak memberikan penghargaan, seperti pujian atau hadiah dibandingkan memberikan hukuman terhadap sikap atau perilaku yang ditampilkan anak. Pengasuh juga tampak memberikan cinta kasih kepada anak TAS tanpa memperlihatkan perbedaan gender.

Pengasuh memiliki pengetahuan tentang penelantaran, eksploitasi, perlakuan salah, kekerasan dan diskriminasi yang dilakukan kepada anak, sehingga pengasuh mengetahui bagaimana melaporkan dan menanggapi pelanggaran tersebut dengan cara menghubungi pekerja sosial jika ada salah seorang anak mengalami hal yang demikian. Saat ini seluruh anak di TAS LN sudah memiliki akta kelahiran dan jika ada yang belum memilikinya maka TAS LN akan membantu dalam proses pembuatan akta kelahiran.

TAS "K”

Di dalam penyelenggaraan TAS, mereka mengetahui tujuan penyelenggaraan TAS bagi AUD dan sudah memiliki ijin pendirian dari Kemensos RI. Namun TAS ini yang terletak di Jakarta Pusat ini belum memiliki acuan dalam menyelenggarakan TAS, serta belum pernah mendengar tentang sistem layanan pengembangan AUD holistik integratif tetapi sudah melakukan kegiatan holistik integratif yang merupakan prinsip pertama penyelenggaraan TAS. Mereka mengetahui penyelenggaraan TAS berbasis hak anak dan mengutamakan kepentingan terbaik bagi anak. Pola pengasuhan anak pun dilakukan secara berkesinambungan, antara TAS, lingkungan keluarga maupun masyarakat tempat anak tinggal. Dalam upaya optimalisasi pertumbuhan dan perkembangan anak, pengasuh sudah mempertimbangkan kearifan budaya lokal dan global seperti mengucapkan terima kasih, maaf, cium tangan, meskipun belum mengajarkan lagu daerah, anak diajarkan tarian daerah pada saat ekstrakurikuler hari Kamis juga diajarkan bermain angklung.

Mereka mengetahui bahwa penyelenggaraan TAS tidak mengambil alih tanggung jawab orang tua tetapi membantu agar orangtua aman, nyaman dan anak mendapat ilmu saat orangtua bekerja. Pengasuh juga sudah menerapkan etika pelayanan terhadap anak.

Layanan kesehatan dan gizi diberikan pengasuh dengan menyediakan perlengkapan P3K serta membantu anak agar mendapatkan imunisasi lengkap, minum suplemen, vitamin A dan minum obat cacing di Posyandu setiap bulan dua kali. Mereka juga mendorong orangtua agar anak memperoleh ASI ekslusif. Pengasuh juga menyajikan menu makanan sehat bergizi seimbang bagi anak serta memantau asupan makanan yang dibawa anak setiap harinya. Mereka memberikan makanan tambahan bagi anak secara berkala. Mereka juga memiliki riwayat kesehatan anak namun tidak melakukan deteksi dini untuk memantau tumbuh kembang anak. Hasil pemantauan pertumbuhan dan perkembangan anak disampaikan ke orangtua secara lisan.

Pemeriksaan kesehatan dasar secara rutin (berat badan, tinggi badan, kuku, rambut, dan lain-lain) dilakukan oleh pengasuh. Pengasuh melakukan pencatatan hasil pemantauan gizi dan kesehatan pengasuh memiliki pengetahuan dan keterampilan dasar untuk menerapkan program gizi dan kesehatan dasar (kesehatan gigi dan tubuh) dengan diarahkan oleh pengelola seperti kepala 
ditutup supaya tidak berantakan dan tangan harus bersih. Namun, mereka tidak melibatkan tenaga ahli dalam menerapkan program gizi dan kesehatan. Mereka juga bekerjasama dengan Puskesmas dan Kalbe Farma dalam memberikan vitamin dan pasta gigi dalam menyelenggarakan layanan kesehatan dan gizi.

Program layanan pendidikan, kegiatan bersama anak yang dilakukan sudah memenuhi kebutuhan dan perkembangan anak. Namun, mereka tidak memiliki acuan dalam merencanakan, mengembangkan dan mengevaluasi stimulasi pertumbuhan dan perkembangan anak dan tidak memiliki acuan pelaksanaan intervensi yang diperoleh dari hasil pemantauan tumbuh kembang anak. Pengelolaan sarana prasarana yang mendukung optimalisasi tumbuh kembang anak seperti alat bermain outdoor sudah dilakukan. Mereka juga menggunakan berbagai media dan sumber belajar yang ramah lingkungan serta mempertimbangkan kearifan lokal seperti dengan menggunakan tutup galon.

Stimulasi yang dilakukan menggunakan prinsip bermain pada AUD. Anak diberikan stimulasi untuk menyukai dirinya dan merasa dihargai misalnya diajarkan untuk menjaga diri sendiri (mata agar tidak tercolok). Anak juga diberikan stimulasi untuk menunjukkan penerimaan akan orang-orang yang memiliki perbedaan yang disampaikan dalam tema "Aku" serta mengajarkan perbedaan laki-laki dan perempuan. Selain itu, anak juga diberikan stimulasi untuk melakukan (1) tugas-tugas sederhana untuk merawat diri sendiri dan membantu orang lain, (2) stimulasi untuk menjadi anak yang kreatif dan gigih dalam menyelesaikan masalah seperti diajarkan untuk membuat gambar sesuai keinginan anak, (3) diberikan stimulasi untuk mengembangkan kemampuan berbahasa dan berpikir setiap hari dengan guru bercerita di depan kelas, (4) diberikan kesempatan untuk mengenali dan mengembangkan kompetensinya dengan diberikan kebebasan sesuai dengan apa yang dia ingin lakukan, (5) didorong untuk dapat mengajukan pertanyaan tanpa rasa takut, serta (6) diberikan kebebasan untuk mengemukakan ide, mengembangkan dan mewujudkannya dengan diminta untuk bercerita atau bertanya. Pengasuh tampak dapat menciptakan lingkungan pembelajaran yang kondusif dan nyaman bagi anak seperti lomba untuk anak yang sedang tidak bahagia, mengajarkan bagaimana mengatasi konflik ketika menghadapi tekanan dari teman sebaya, serta melatih kemandirian anak. Namun di sisi lain, pengasuh belum memliki pengetahuan dan keterampilan yang dapat mendukung tercapainya tumbuh kembang anak yang optimal. Selain itu, TAS bermitra dengan Rumah Sakit St. Carolus untuk mengadakan melalui kegiatan seminar tentang pendidikan seks.

Dalam program layanan pengasuhan dan perlindungan, anak diajarkan untuk dapat mengetahui nama dan alamat orangtua/wali saat tema "Aku". Mereka memiliki program tentang pencegahan, tanggap darurat, rehabilitasi dan konstruktif terhadap bencana yang dikenalkan dalam program pembelajaran. TAS juga memiliki program pemeliharaan dan perawatan sarana dan prasarana yang dilakukan secara berkala yaitu habis bermain disimpan dan dicuci setiap hari. Namun, tidak semua anak yang ada di sana sudah memiliki akta kelahiran. Mereka juga sudah menerapkan pembiasaan hidup bersih dan sehat (PHBS) yaitu senin pemeriksaan kuku, namun menggosok gigi belum dilaksanakan karena belum ada bantuan dari "lion".

Di sisi lain, pengasuh belum memiliki pengetahuan tentang penelantaran, ekploitasi, perlakuan salah, kekerasan dan diskriminasi. Pengasuh hanya mengetahui sekilas bahwa anak tidak boleh galak terhadap anak. Pengasuh memberikan cinta dan kasih sayang yang dibutuhkan anak melalui pelukan dan pangkuan. Pengasuh juga terbiasa untuk memberikan penghargaan kepada anak atas usaha baik yang telah dilakukan seperti memberikan reward berupa biskuit atau pujian. Pengasuh dan anak mengetahui untuk melaporkan dan menanggapi pelanggaran perlindungan anak.

Mereka juga menyelenggarakan kegiatan penyuluhan, diskusi, simulasi dan seminar demi mencapai hasil terbaik untuk anak, misalnya dengan memanggil ustadz dan memberikan kegiatan penguatan orangtua dalam rangka praktik pengasuhan dan perlindungan anak. Setiap akhir bulan dilakukan evaluasi di dalam kelas.

TAS berkoordinasi dengan masyarakat untuk mendapatkan dukungan ide dan pembiayaan dalam pemberian layanan dengan bantuan berupa barang maupun uang, dan bekerjasama dengan pekerja sosial dalam menjalankan program sebagai salah satu syarat dalam menjalankan kegiatan pelaporan dan evaluasi. Pengasuh memastikan lingkungan, alat dan bahan main yang digunakan anak dalam kondisi 
aman, nyaman, dan menyenangkan. Pengasuh juga mengajarkan tentang perlindungan diri dengan mengenalkan kepada anak bagian tubuh yang boleh dan tidak boleh disentuh serta memisahkan anak laki-laki dan perempuan saat mandi.

Pengasuhan juga sudah dilakukan tanpa diskriminasi gender dan melibatkan orangtua dalam melakukan kegiatan bersama anak. Adapun mitra TAS terkait perlindungan dan pengasuhan adalah dengan bekerjasama dengan Pengacara, Polsek Catatan dan Pendudukan Sipil.

\section{TAS AK}

Pengelola TAS mengetahui tujuan penyelenggaraan TAS bagi AUD dan memiliki ijin pendirian serta acuan dalam menyelenggarakannya. Mereka mengetahui penyelenggaran TAS berbasis hak anak dan mengutamakan kepentingan terbaik bagi anak. Pola pengasuhan anak dilakukan secara berkesinambungan antara TAS, lingkungan keluarga, dan masyarakat tempat anak tinggal. Mereka mengetahui bahwa penyelenggaraan TAS tidak mengambil alih tanggung jawab orang tua. Mereka sudah menerapkan etika pelayanan terhadap anak. Mereka memiliki mitra kerjasama dalam menyelenggarakan layanan pendidikan serta kesehatan dan gizi, layanan stimulasi pendidikan, layanan pengasuhan dan perlindungan, serta layanan kesejahtaraan namun upaya optimalisasi pertumbuhan dan perkembangan anak di TAS belum mempertimbangkan kearifan budaya lokal serta global. Selain itu, mereka tidak pernah mendengar tentang sistem layanan PAUD HI.

Dalam program layanan kesehatan dan gizi, mereka memiliki perlengkapan P3K, mendorong orangtua agar anak memperoleh ASI ekslusif, dan menyajikan menu makanan sehat bergizi seimbang bagi anak serta mereka juga memberikan makanan tambahan bagi anak secara berkala. Pengasuh juga sudah melakukan pemeriksaan kesehatan dasar secara rutin (berat badan, tinggi badan, kuku, rambut, dan lain-lain) serta melakukan deteksi dini untuk memantau tumbuh kembang anak namun hasil pemantauan tersebut tidak dicatat. Hasil pemantauan pertumbuhan dan perkembangan anak disampaikan kepada orangtua. Tenaga ahli tetap dilibatkan dalam menerapkan program gizi dan kesehatan meskipun pengasuh sudah memiliki pengetahuan dan keterampilan dasar, terutama yang terkait dengan kesehatan gigi dan tubuh. Namun, mereka belum membantu anak untuk mendapatkan imunisasi lengkap, minum suplemen vitamin A, dan minum obat cacing. Pengasuh juga tidak memantau asupan makanan yang dibawa anak setiap harinya

Dalam program layanan pendidikan, kegiatan bersama anak yang dilakukan sudah cukup memenuhi kebutuhan dan perkembangan anak. Mereka juga memiliki acuan dalam merencanakan, mengembangkan dan mengevaluasi stimulasi pertumbuhan dan perkembangan yang diberikan kepada anak dan acuan pelaksanaan intervensi yang diperoleh dari hasil pemantauan tumbuh kembang anak. Pengelolaan sarana dan prasarana di lingkungan mereka cukup dapat mendukung optimalisasi tumbuh kembang anak. Mereka juga sudah menggunakan berbagai media dan sumber belajar yang ramah lingkungan serta mempertimbangkan kearifan lokal. Stimulasi yang dilakukan menggunakan prinsip-prinsip bermain pada anak usia dini, anak diberikan stimulasi untuk menyukai dirinya dan merasa dihargai, melakukan tugas sederhana untuk merawat diri sendiri dan membantu orang lain, menjadikan anak kreatif dan gigih dalam menyelesaikan masalah, mengembangkan kemampuan berbahasa dan berpikir setiap hari, mengenali serta mengembangkan kompetensinya. Selain itu, anak juga distimulasi untuk dapat mengajukan pertanyaan tanpa rasa takut agar anak lebih berani dan percaya diri, diberikan kebebasan untuk mengemukakan ide, mengembangkan dan mewujudkan idenya.

Pengasuh memiliki pengetahuan dan keterampilan yang dapat mendukung tercapainya tumbuh kembang anak yang optimal. Pengasuh cukup dapat menciptakan lingkungan pembelajaran yang kondusif dan nyaman bagi anak dan mengajarkan bagaimana menghadapi tekanan dari teman sebaya serta melatih kemandirian anak. Namun, mereka tidak memberikan stimulasi bagaimana menerima perbedaan yang ada pada setiap manusia.

Dalam program layanan pengasuhan dan perlindungan, anak-anak sudah memiliki akta kelahiran dan diajarkan untuk dapat mengetahui nama dan alamat orangtua. Mereka sudah menerapkan pembiasaan hidup bersih dan sehat (PHBS). Pengasuh memiliki pengetahuan tentang penelantaran, ekploitasi, perlakuan salah, kekerasan dan diskriminasi. Mereka membantu orangtua/ keluarga yang belum memiliki akta kelahiran dan cara akses layanan kesehatan. Pengasuh tampak memberikan cinta dan kasih sayang yang dibutuhkan 
anak, terbiasa untuk memberikan penghargaan kepada anak atas usaha baik yang telah dilakukan. Pengasuh dan anak mengetahui bagaimana melaporkan dan menanggapi pelanggaran perlindungan anak. Pengasuhan juga sudah dilakukan tanpa diskriminasi gender dan melibatkan orangtua dalam melakukan kegiatan bersama anak.

Mereka juga menyelenggarakan kegiatan penyuluhan, diskusi, simulasi dan seminar untuk hasil yang terbaik untuk anak. Mereka memberikan kegiatan penguatan orangtua berkoordinasi dengan masyarakat untuk mendapatkan dukungan ide dan pembiayaan dalam pemberian layanan. Mereka bekerjasama dengan pekerja sosial dalam menjalankan program. Mereka juga sudah berkoordinasi dengan masyarakat untuk mendapatkan dukungan ide dan pembiayaan dalam pemberian layanan. Pengasuh memastikan lingkungan alat dan bahan main yang digunakan anak dalam kondisi aman, nyaman dan menyenangkan dan pengasuh juga mengenalkan kepada anak bagian tubuh yang boleh dan tidak boleh disentuh. Namun, mereka tidak memiliki progam pemeliharaan dan perawatan sarana dan prasarana yang dilakukan secara berkala. Mereka juga tidak memiliki program tentang pencegahan, tanggap darurat, rehabilitasi dan konstruktif terhadap bencana.

\section{Perbandingan Ketiga TAS}

Hasil penelitian yang dilakukan di ketiga TAS dalam hal pemberian layanan kesehatan dan gizi, layanan pendidikan, serta layanan pengasuhan dan perlindungan adalah (1) Layanan Kesehatan dan Gizi: pengasuhan di TAS LN yang sudah menerapkan layanan kesehatan dan gizi sementara dua TAS lainnya masih memerlukan peningkatan kualitas layanan agar menjadi lebih baik; (2) Layanan Pendidikan: pengasuh di TAS AK sudah pernah mendapatkan pelatihan terkait pengasuhan sedangkan dua TAS lainnya belum sehingga layanan pendidikan yang diberikan oleh TAS AK paling sedikit memiliki kekurangan; serta (3) Layanan Pengasuhan dan Perlindungan: pengasuh di TAS "K" telah menerapkan layanan pengasuhan dan perlindungan dengan membuat program tentang pencegahan, tanggap darurat, rehabilitasi, dan konstruktif terhadap bencana meskipun pengasuhnya tidak memiliki pengetahuan terkait penelantaran, eksploitasi, perlakukan salah, kekerasan dan diskriminasi. Kedua TAS lainnya, tidak memiliki program tentang pencegahan, tanggap darurat, rehabilitasi, dan konstruktif terhadap bencana.

\section{PENUTUP}

\section{Kesimpulan}

Pengasuh di TAS LN baru dapat memberikan layanan kesehatan dan gizi serta layanan pendidikan, sementara layanan pengasuhan dan perlindungan belum sepenuhnya dilakukan; Pengasuh di TAS "K" dapat memberikan layanan pengasuhan dan perlindungan dengan baik, namun layanan kesehatan dan gizi serta layanan pendidikan masih perlu diperhatikan; Pengasuh di TAS AK belum dapat memberikan ketiga layanan sebagaimana seharusnya meskipun pengasuh dan pengelolanya sudah pernah mendapatkan pelatihan terkait pengasuhan. Pengasuh di ketiga TAS belum dapat memberikan layanan pengasuhan yang sesuai dengan tujuan penyelenggaraan TAS, yaitu anak belum mendapatkan jaminan tumbuh kembang berupa pengasuhan, perawatan dan perlindungan; pengasuh belum dapat menyediakan kesempatan bagi anak untuk memperoleh pengasuhan, perawatan, perlindungan baik yang dapat terjamin kelangsungan hidup, tumbuh kembang dan partisipasi bagi anak.

Ketiga TAS terlihat belum memiliki kemampuan untuk memberikan pelayanan pengasuhan dan perawatan kepada anak untuk menggantikan peran orang tua yang sedang bekerja.

\section{Saran}

Pertama, para pengasuh diberikan pengayaan pengetahuan dan keterampilan secara bertahap dan berkelanjutan terkait optimalisasi tumbuh kembang AUD dan Pengembangan anak usia dini holistik integratif. Kedua, dibutuhkan norma, standar, prosedur, dan kriteria turunan dari kebijakankebijakan terkait penyelenggaraan TAS di lingkungan Kemensos RI agar dapat menjadi panduan bagi penyelenggara TAS dan memudahkan dalam monitoring dan evaluasi program yang telah dijalankan. Ketiga, Kemensos RI perlu meningkatkan sosialisasi tentang penyelenggaraan TAS kepada masyarakat. 


\section{DAFTAR PUSTAKA}

BAPPENAS. (2009). Pedoman umum pengembangan anak usia dini holistik integratif. Jakarta.

Direktorat Pembinaan PAUD Dirjen PAUD dan DIKMAS, Kementerian Pendidikan dan Kebudayaan. (2015). Petunjuk teknis penyelenggaraan taman penitipan anak. Kementerian Pendidikan dan Kebudayaan. Jakarta.

Direktorat Pembinaan PAUD Dirjen PAUD dan DIKMAS, Kementerian Pendidikan dan Kebudayaan. (2015). NSPK: Petunjuk teknis penyelenggaraan PAUD HI di satuan PAUD. Jakarta.

Hastuti, D. (2010). Pengasuhan : Teori, prinsip dan aplikasinya di Indonesia. Bogor: IPS Press.
Hoghughi, M. \& Long, N. (2004). Handbook of parenting: Theory and research for practice. UK. SAGE Publications Ltd.

Moleong, L.J., (2012). Metodologi penelitian kualitatif. Edisi Revisi. Bandung: PT. Remaja Rosdakarya.

Peraturan Presiden No.60 Tahun 2013 tentang Pengembangan anak usia dini holistik integratif (PAUD HI).

Peraturan Menteri Sosial Republik Indonesia No.2 tahun 2012 tentang Taman Anak Sejahtera.

Peraturan Menteri Sosial Republik Indonesia No.21 tahun 2013, tentang Pengasuhan.

Surya, S. (2007). Melejitkan multiple intelligence anak sejak dini. Yogyakarta: ANDI. 